\title{
OBILJEŽJA POKRETA OČIJU I MODELI ČITANJA UTEMELJENI NA UPORABI UREĐAJA ZA PRAĆENJE POKRETA OČIJU
}

\author{
ANA MATIĆ \\ Odsjek za logopediju, Edukacijsko-rehabilitacijski fakultet Sveučilišta u Zagrebu, kontakt: ana.matic@erf.hr \\ Pregledni rad \\ UDK: 81'232: 612.84
}

Primljeno: 09.02.2017.

Prihvaćeno: 11.09.2017.

Sažetak: U posljednjih su nekoliko desetljeća razvijene brojne metode s ciljem rasvjetljavanja mehanizama jezične obrade. Ugrubo se mogu podijeliti na metode koje se provode u odgođenom i u stvarnom vremenu (u ovome će se radu koristiti izvorni engleski izrazi off-line i on-line), pri čemu ih razlikuje način primjene te vrsta i obilježja podataka koje pružaju. Metoda praćenja pokreta očiju (engl. eye-tracking) danas se smatra jednom od najboljih metoda za proučavanje jezične obrade. Ona daje uvid u procese kognitivne obrade u stvarnom vremenu, a za razliku od off-line, ali i nekih on-line metoda, npr. metode mjerenja evociranih potencijala ili funkcionalne magnetske rezonancije, naročito je pogodna za istraživanje procesa koji se protežu u vremenu. Budući da je utemeljena na pretpostavkama koje povezuju fiziološku razinu kontrole pokreta oka s kognitivnim procesima koji su u pozadini, a pritom je i neinvazivna, danas je ovo sve zastupljenija metoda u proučavanju procesa vezanih za jezičnu obradu.

Glavni je cilj ovog rada dati kratki pregled metoda istraživanja jezične obrade s posebnim naglaskom na on-line metodu praćenja pokreta očiju, predstaviti obilježja pokreta očiju tijekom čitanja te pružiti prikaz nekih od danas najaktualnijih modela čitanja. Iako se jezična obrada može proučavati i putem čitanja i putem slušanja, za potrebe ovog rada naglasak je stavljen na paradigmu čitanja.

Ključne riječi: jezična obrada, on-line metode, praćenje pokreta očiju, modeli čitanja.

\section{METODE ISTRAŽIVANJA JEZIČNE OBRADE S NAGLASKOM NA ON-LINE METODU PRAĆENJA POKRETA OČIJU}

\section{Off-line metode istraživanja jezične obrade}

Veliki broj studija koje nastoje rasvijetliti procese jezičnog razumijevanja utemeljen je na tzv. off-line eksperimentima kojima se pokušava odgovoriti na pitanje kako djeca i odrasli urednog ili narušenog jezičnog razvoja razumiju riječi i rečenice (Marinis, 2010). Neki su od primjera metoda procjene jezičnog razumijevanja zadatci procjene istinitosti tvrdnji (njihov opis detaljnije je prikazan u Gordon, 1998), zadatci procjene gramatičnosti (v. primjerice Tremblay, 2005 ili McKercher i Jaswal, 2011), zadatci izvedbe (više u Goodluck, 1998) i zadatci odabira slika (detaljnije u Gerken i Shady, 1998). Još sveobuhvatniji pregled metoda kojima se procjenjuju jezično razumijevanje, ali i proi- zvodnja može se pronaći u Ambridge i Rowland (2013).

Njihove su glavne prednosti to što su primjenjivi u više domena i situacija, ekonomični su i lako se interpretiraju (Schmitt i Miller, 2010). S druge strane, njihov je glavni nedostatak činjenica da mjere ispitanikovo ponašanje nakon što je ispitaniku prikazan cijeli zadatak, npr. izgovorena cijela rečenica, što značajno opterećuje kapacitet radnog pamćenja (ispitanik mora čuti i zapamtiti zadatak, obraditi ga te naknadno reagirati ovisno o tipu zadatka). Nedostatak je i nemogućnost jasnog razgraničavanja jezičnog od metajezičnog znanja, što se najbolje može prikazati na primjeru zadataka odabira slika. Ispitanik donosi kontroliranu i svjesnu odluku o značenju rečenice prije nego pokaže sliku, pri čemu ima vremena za razmišljanje pa istovremeno uključuje i eksplicitna znanja o jeziku i metajezične sposobnosti, zbog čega se same jezične sposobnosti lako mogu precijeniti ili podcijeni- 
ti. Osim toga, primjenjujući off-line zadatke nije moguće izmjeriti ispitanikov nesvjesni i automatski odgovor na jezični podražaj (Marinis, 2010). Ovi se nedostatci mogu premostiti upravo primjenom on-line metoda.

\section{On-line metode istraživanja jezične obrade}

On-line metodama kojima se može istražiti jezična obrada bilježi se vrijeme reakcije, promatraju pokreti oka tijekom čitanja ili slušanja te ispituje moždana aktivnost tijekom izvođenja zadataka (Sekerina i sur., 2008). U ovu kategoriju ulaze metode oslikavanja mozga (one uključuju metodu kognitivnih evociranih potencijala (KEP; engl. ERP) te funkcionalnu magnetsku rezonancu (fMRI); mjerenje vremena reakcije (engl. reaction time; $R T)$; metoda mjerenja čitanja vlastitom brzinom (engl. self-paced reading; $S P R$ ) i metoda praćenja pokreta očiju (engl. eye-tracking; ET). Posljednje tri puno su dostupnije, jednostavnije za primjenu i češće upotrebljavane od metoda oslikavanja mozga.

Mjerenje vremena reakcije je zaživjelo u 19. stoljeću, međutim u jezičnim se istraživanjima počelo koristiti nakon Chomskyjeve revolucije 1950-ih godina (Jiang, 2013). Pogodno je za primjenu u bilo kojoj empirijskoj studiji u kojoj se na temeljno istraživačko pitanje odgovara mjerenjem i analizom vremena koje je ispitaniku potrebno za izvršenje određenog zadatka ili odgovaranje na podražaj. Promatra se brzina ispitanikova odgovora, tj. latencija odgovora, a vrijeme se bilježi u milisekundama (Jiang, 2013). Primjeri zadataka u kojima se može mjeriti vrijeme reakcije jesu zadatak leksičke odluke (engl. lexical decision task) u kojem osoba donosi odluku je li nešto riječ ili neriječ, ili primjerice zadatak imenovanja slika (engl. picture naming task) u kojem osoba mora što brže imenovati prikazanu sliku. Četiri su glavne karakteristike istraživanja koja promatraju vrijeme reakcije: točnost mjerenja, strogost u manipuliranju varijablama, procjena ponašanja u odnosu na vrijeme te progresivna narav metode (detaljnije u Jiang, 2013; str. 3-7, a za temeljit prikaz mjerenja vremena reakcije v. Jensen, 2006). Neke od prednosti mjerenja vremena reakcije jesu mogućnost ispitivanja različitih jezičnih domena i sastavnica, mogućnost osmišljavanja i kreiranja vlastitih zadataka ovisno o području koje se želi istražiti, dobivanje mnogo osjetljivijih podataka o mentalnim reprezentacijama jezičnog znanja nego je to slučaj s drugim metodama te davanje uvida u točno vrijeme aktivacije različitih informacija ili strategija obrade. Dakako, postoje i neki nedostatci poput činjenice da je metoda manje izravna od onih koje uključuju podatke o pogreškama i točnim odgovorima, vrijeme reakcije samo po sebi nije jezično ponašanje već je pod utjecajem brojnih drugih čimbenika koje nije jednostavno kontrolirati te se dobiveni podatci o jezičnom znanju i obradi češće mogu primijeniti na grupu ispitanika nego na pojedinca (Jiang, 2013).

Metoda koja koristi paradigmu čitanja vlastitom brzinom u psiholingvistici se pojavila 1970-ih godina kao posljedica težnje kognitivnih psihologa da se jezično razumijevanje mjeri u stvarnom vremenu (Jegerski, 2014). Ona otkriva psihološke procese koji se odvijaju u pozadini dok osoba razumijeva određeni tekst te daje uvid u vremensku dimenziju procesa razumijevanja (Just i sur., 1982). Metoda je jednostavna jer je podražaj (najčešće riječ) prikazan na ekranu pri čemu je osoba ta koja pritiskom tipke kontrolira kada će se pojaviti iduća riječ. Dakle, svaki je sljedeći podražaj maskiran, tj. skriven dok osoba ne pročita onaj koji joj je trenutačno dostupan. Glavna je pretpostavka metode tvrdnja da odgođeno vrijeme pritiska tipke podrazumijeva veće teškoće jezične obrade (Just i sur., 1982). Prednosti su što se metoda može primijeniti na puno različitih jezičnih fenomena i što iziskuje vrlo malo opreme, zbog čega se može koristiti i izvan strogo laboratorijskih uvjeta (Clahsen, 2008). Iako je lako primjenjiva i ekonomična, metodu karakteriziraju i neki nedostatci poput manjka prirodnosti u procesu čitanja (ljudi inače ne čitaju riječ po riječ već pogledom zahvaćaju i okolne tekstualne informacije, a pritiskanje tipke dodatan je distraktor), kao i činjenice da metoda nužno usporava proces čitanja i sam proces davanja odgovora $u$ odnosu na druge metode (Carreiras i Clifton, 2004; Clahsen, 2008; Jegerski, 2014).

Kako bi se navedeni nedostatci prevladali, postoji mogućnost upotrebe sofisticiranije i sve raširenije metode - metode praćenja pokreta očiju - koja ispitivačima pruža više informacija nego je to slučaj s prethodno opisanim metodama. 


\section{Metoda praćenja pokreta očiju}

Ova je metoda svoje rane začetke doživjela 1879. godine kada je Emile Louis Javal primijetio da ljudi pogledom prolaze kroz tekst nesustavnom brzinom, preskačući neke dijelove, a zaustavljajući se na drugima. Početkom 20. stoljeća započinje se s prvim istraživanjima, a razvojem novih metodoloških pristupa i kognitivnih teorija obrade u posljednjoj trećini 20. stoljeća nastupa novi val istraživanja pokreta očiju (Carreiras i Clifton, 2004; Rayner, 1998). Danas se istraživanja utemeljena na praćenju pokreta očiju uspješno primjenjuju u različitim komponentama jezične obrade: fonološka i ortografska obrada (primjerice, Lee i sur., 1999), obrada slogova (primjerice, Ashby i Rayner, 2004), leksička dvosmislenost (primjerice, Dopkins i sur., 1992), morfološka obrada (primjerice, Pollatsek i sur., 2000), sintaktička obrada (primjerice, Kamide i sur., 2003) i sl. Detaljniji pregled specifičnih istraživanja može se pronaći u Rayner (1998, str. 390). Dvije glavne paradigme koje se rabe u takvim istraživanjima jesu praćenje i mjerenje pokreta očiju tijekom čitanja (vidi primjerice Rayner, 1998) i tijekom slušanja (vidi primjerice Tanenhaus i sur., 1995). Za potrebe ovog rada naglasak je stavljen na čitanje.

U primjeni ove metode klasični zadatci uključuju elemente off-line zadataka, kao što je primjerice zadatak odabira slika ili odgovarajuće rečenice. Off-line metode pritom u obzir uzimaju samo zadnji odgovor ispitanika, dok metoda praćenja pokreta očiju daje mnogo više informacija, budući da se tijekom mjerenja prikupljaju podatci o pokretima očiju prije samog donošenja odluke i davanja odgovora. Bitna prednost ove metode nad off-line i nekim on-line metodama, u kojima odgovor ne mora nužno odražavati unutarnje kognitivne procese, jest to što se ovom metodom sprječava mogućnost maskiranja potencijalnih pozadinskih nesigurnosti u odabiru odgovora pa sve strategije odlučivanja postaju razvidne (Sedivy, 2010). Nadalje, prednost je i njezina osjetljivost na vremensku dimenziju; metoda pruža jasniju sliku o obradi, dajući konkretan odgovor na pitanja kako i kada se nešto događa. Kada se u psiholingvistici govori o jezičnom razumijevanju, jedna je od prvih stvari koja se napominje takozvana inkrementalnost. Ona podrazumijeva da se semantičke veze stvaraju u samom trenutku čitanja (ili slušanja): riječ-po-riječ (primjerice, Altmann i Steedman, 1988) ili, ako se radi o razumijevanju teksta, s manjim stupnjem odgode, odnosno nakon čitanja većih cjelina kao što su rečenice (primjerice, Millis i Just, 1994). Drugim riječima, osoba ne prima jezične podatke bez razumijevanja dok joj se na kraju rečenice u glavi ne pritisne neki klik pa onda odjednom shvati smisao, nego se značenje rečenice gradi riječ po riječ, kako one osobi dolaze, uz njezine implicitne pretpostavke kamo rečenica smjera. Metoda praćenja pokreta očiju omogućuje uvid u te procese, odnosno njihov tijek, praćenjem duljine zadržavanja na pojedinoj riječi, broja pokreta očiju unazad ili brzine kojom čitatelj prelazi preko teksta. Nadalje, omogućuje i uvid u to je li došlo do neuspjeha $\mathrm{u}$ interpretaciji zadatka ili do preopterećenosti sustava obrade, a pogodna je za istraživanje jezika ljudi svih životnih dobi (Sedivy, 2010). Ipak, iako je moguće dobiti velik broj navedenih varijabli (zadržavanje na riječi, broj vraćanja na prethodnu riječ i slično), još je uvijek nedovoljno jasno koje su mjere pokreta očiju najosjetljivije i samim time najpogodnije za istraživanje pojedinih fenomena (Sedivy, 2010).

\section{Glavna obilježja pokreta očiju}

Kako je već ranije u tekstu spomenuto, jezična se obrada može proučavati u različitim jezičnim djelatnostima. Za potrebe ovoga rada naglasak je stavljen na paradigmu čitanja, kojom se može steći jasan uvid u jezičnu obradu.

Prilikom čitanja ili promatranja određene scene, oči se ne kreću u pravilnim razmacima već čine malene skokovite pokrete koji se zovu sakade. Ti se pokreti nazivaju balističkima što znači da, jednom kada su programirani i učinjeni, više ne mijenjaju svoj smjer i domet. Tipičan čitatelj napravi tri ili četiri sakade u sekundi, a duljina sakade varira ovisno o različitim čimbenicima i uvjetima. Smatra se da u čitanju naglas ona obuhvaća otprilike šest grafema (Rayner, 1984; 1998). Čitatelj preskače čak 25-30\% riječi u tekstu, pri čemu značajnu ulogu ima duljina riječi (kraće riječi preskaču se češće nego duge) te predvidljivost i čestotnost u nešto manjoj mjeri (Rayner, 2009). Čak 90\% čitanja čine tzv. fiksacije, što je vrijeme u kojem su pokreti oka relativno stabilni. Oči prilikom čitanja 
ostaju fiksirane 200 do $400 \mathrm{~ms}$ (Carreiras i Clifton, 2004), a najčešće ipak oko 250 ms (Rayner, 2009), nakon čega slijedi ili spomenuti skok (sakada) ili regresija, odnosno pokret u suprotnom smjeru, tj. povratak na prethodno fiksirano područje. Smatra se da do regresija dolazi ili zbog prethodne sakade koja je bila predugačka ili zbog nepotpunog razumijevanja prethodnog sadržaja, odnosno poteškoća u obradi. Regresije čine $15 \%$ svih pokreta očiju (Rayner, 1998; 2009). Odavno je poznato da se razvojno te s porastom vještine čitanja ova obilježja mijenjaju: trajanje fiksacija se smanjuje, duljina sakada raste te se broj fiksacija i učestalost regresija smanjuju (Buswell, 1922).

Spoznaja koja je uvelike utjecala na sva sljedeća istraživanja jest ona do koje su došli Just i Carpenter (1980), a tiče se činjenice da mjere pokreta očiju mogu osvijetliti kognitivne procese koji se odvijaju tijekom čitanja u stvarnom vremenu. Došli su do dvije ključne pretpostavke: jedna je takozvana pretpostavka neposrednosti (engl. immediacy assumption) prema kojoj je riječ glavna jedinica obrade, a čitatelj interpretira upravo onu riječ koju trenutno fiksira; dok je druga pretpostavka oko-um (engl. eye-mind assumption) prema kojoj postoji jaka veza između onoga u što osoba gleda i na što misli, tj. što u umu obrađuje, čime se fiziološka razina kontrole pokreta oka povezuje s kognitivnim procesima koji su u pozadini (o potencijalnim ograničenjima ove pretpostavke v. u Anderson i sur., 2004).

Ipak je nužno napomenuti i pojavu do koje može doći tijekom čitanja, a koju navedena spoznaja i neke druge teorije ne uzimaju u obzir (primjerice, Henderson i Ferreira, 1990; Morrison, 1984), a to je da obrada riječi ne završava nužno u trenutku kad oko napusti tu riječ, odnosno kad nastupi sakada. To je tzv. učinak prelijevanja (engl. spill-over effect) (v. Schroyens i sur., 1999) koji podrazumijeva činjenicu da složenost riječi $n$ utječe na trajanje fiksacije na riječi $n+1$. Što je riječ $n$ složenija za obradu, manje vremena preostaje za obradu riječi $n+1$, stoga se složenost riječi $n$ 'prelijeva', čime se produžuje trajanje fiksacije na sljedećoj riječi $(n+1)$ (Pollatsek i sur., 2006). Dokazano je primjerice da čestotnost fiksirane riječi utječe na obradu riječi koja slijedi nakon što je prva riječ fiksirana, a što se očituje produljenjem fiksacije na sljedećoj riječi (Rayner i Duffy, 1986).

U mnogim je istraživanjima primijećena još jedna bitna pojava, a to je takozvani učinak završavanja (engl. wrap-up effect) koji podrazumijeva da čitatelj više vremena provodi čitajući posljednje riječi u rečenici nego čitajući riječi u središnjem dijelu rečenice (primjerice, Aaronson i Scarborough, 1976; Just i Carpenter, 1980,...). U najvećem se broju istraživanja ovaj učinak pripisuje većem stupnju obrade povezanim s unutar- i među-rečeničnom integracijom. Ipak, u novije se vrijeme ova postavka preispituje i navedeni se učinak dovodi u vezu i s drugim čimbenicima poput okulomotornog oklijevanja pod utjecajem rečeničnih znakova (Hill i Murray, 2000) i slično (vidi više u Warren i sur., 2009).

\section{MODELI ČITANJA}

Na čitanje, kao složenu vještinu kojom se postupno ovladava, utječe velik broj čimbenika ${ }^{1}$ stoga je objašnjenje fenomena vezanih za čitanje teško, a za najveći broj pitanja još uvijek nema općeg slaganja. Iako nažalost ne postoji sveobuhvatni model koji dotiče sve procese usko vezane uz čitanje i koji je usmjeren na sve čimbenike koji utječu na čitanje (Rayner i Reichle, 2010), suvremeni modeli ipak uspijevaju objasniti velik broj fenomena vezanih za ovu vještinu. Rayner (2009) u svom radu, u kojem problematizira modele i vrstu podataka koje metoda praćenja pokreta očiju daje, vrlo jasno i otvoreno navodi da svi modeli, kako bi bili valjani, u obzir nužno moraju uzeti obilježja pokreta očiju navedena u prethodnom poglavlju (fiksacije, sakade, regresije), kao i njihovo trajanje i čimbenike koji ih određuju.

Modeli razvijeni radi objašnjenja pitanja kontrole pokreta očiju mogu se podijeliti u dvije vrste: 1) one u kojima su pokreti oka određeni primarno okulomotornim čimbenicima (tzv. modeli okulomo-

1 Ovi su čimbenici raznoliki i mogu se promatrati s obzirom na pojedinca i njegovu okolinu (kognitivni i senzorički čimbenici, motivacija,...; vidi Snow i sur., 1998), obilježja samog teksta (kvaliteta tiska i vrsta fonta, duljina retka, razmak između grafema, obilježja ortografskog sustava, ...; vidi Kolers i sur., 1981; Morrison i Inhoff, 1981; Osaka, 1989), ali kada govorimo o pokretima očiju važni su i čimbenici na razini sintakse (učinak dvosmislenosti rečenice, sintaktička složenost, sintaktička narušenost, ...; za detaljan pregled ovih čimbenika vidi Clifton i Staub, 2011). 
torne kontrole) te 2) one u kojima su pokreti oka vođeni kognitivnim procesima (tzv. modeli obra$d e$ ). Potonji naglašavaju ulogu jezične obrade tijekom čitanja pa tako smatraju da je odluka o tome koliko će dugo trajati fiksacija određena jezičnom obradom, dok je pitanje lokacije fiksacije određeno kako jezičnim, tako i vizualnim i okulomotornim čimbenicima (Reichle i Rayner, 2000). U ovom radu ukratko se prikazuju dva najutjecajnija i u literaturi najčešće spominjana modela koja pripadaju drugoj navedenoj skupini modela: E-Z Reader (Reichle i sur., 1998; uz kasnije inačice: Reichle i sur., 2003; Pollatsek i sur., 2006; Reichle i sur., $2009, . .$.$) te SWIFT (Engbert i sur., 2002; uz kasnije$ inačice: Engbert i sur., 2004; Engbert i sur., 2005; Richter i sur., 2006,...). Kratak popis preostalih najpoznatijih modela prikazan je u Tablici 1.

Tablica 1. Najpoznatiji modeli čitanja s naglaskom na vrstu modela (modeli okulomotorne kontrole i modeli obrade). Preuzeto od Rayner (2009).

\begin{tabular}{|l|l|}
\hline Model & Vrsta modela \\
\hline $\begin{array}{l}\text { E-Z Reader } \\
\text { Reichle, Pollatsek, Fisher i } \\
\text { Rayner, 1998 }\end{array}$ & Model obrade \\
\hline $\begin{array}{l}\text { SWIFT } \\
\text { Engbert, Longtin i Kliegl, } \\
2002\end{array}$ & Model obrade \\
\hline $\begin{array}{l}\text { EMMA } \\
\text { Salvucci, 2001 }\end{array}$ & Model obrade \\
\hline $\begin{array}{l}\text { Glenmore } \\
\text { Reilly i Radach, 2006 }\end{array}$ & Model obrade \\
\hline $\begin{array}{l}\text { SERIF } \\
\text { McDonald, Carpenter i } \\
\text { Shillcock, 2005 }\end{array}$ & $\begin{array}{l}\text { Model okulomotorne } \\
\text { kontrole }\end{array}$ \\
\hline $\begin{array}{l}\text { Competition/Activation } \\
\text { Yang i McConkie, 2001 }\end{array}$ & $\begin{array}{l}\text { Model okulomotorne } \\
\text { kontrole }\end{array}$ \\
\hline $\begin{array}{l}\text { SHARE } \\
\text { Feng, 2006 }\end{array}$ & $\begin{array}{l}\text { Model okulomotorne } \\
\text { kontrole }\end{array}$ \\
\hline
\end{tabular}

\section{Model E-Z Reader}

E-Z Reader (Rayner i sur., 1998) jest model koji se smatra jednim od najpoznatijih i najutjecajnijih u ovom području. Danas postoji više njegovih inačica, od kojih je prvih nekoliko opisano u Reichle i sur. (1998), a preostale primjerice u Reichle i sur. (2003), Pollatsek i sur. (2006) itd. U svim inačicama modela, upravo je leksička obrada ono što uvjetuje pokrete očiju. Dvije su faze leksičke obrade prisutne kada čitatelj fiksira riječ. U prvoj fazi (L1) koja traje nekoliko milisekundi, donosi se odluka o tome je li fiksirana riječ $(n)$ poznata ili ne (tzv. provjera poznatosti; engl. familiarity check). Kada se prijeđe određeni prag, okulomotornom se sustavu šalje signal i počinje programiranje sakade odnosno preusmjeravanje pažnje prema sljedećoj, neidentificiranoj riječi u tekstu. Ova se faza (L2) naziva dovršavanje leksičkog pristupa (engl. completion of lexical access) i pažnja je tada u potpunosti usmjerena na riječ $n+1$. Same sakade programiraju se u dvije faze: prvoj, labilnoj (MI) koja se može prekinuti uslijed drugih programiranja sakada i drugoj, nelabilnoj fazi (M2) koja se, jednom kada je započeta, više ne može prekinuti.

Iznimno je bitno napomenuti da je ovaj model serijski, tj. da podrazumijeva postupno preusmjeravanje pažnje $(n$, zatim $n+1$, pa $n+2, \ldots)$ te da su obje navedene faze pod izravnim utjecajem obilježja riječi, odnosno da je leksička obrada ono što uvjetuje pokrete očiju tijekom čitanja teksta.

Ako su postavke modela o tome kako je identifikacija riječi u interakciji s pažnjom i sustavom pokretanja očiju ispravne, tada podatci o pokretima oka zaista mogu rasvijetliti kognitivne i jezične procese uključene u čitanje. Iako se čini da je izjednačavanje samog trajanja pogleda s procesom identifikacije riječi pojednostavljivanje cijelog postupka, prema ovome je modelu potpuno razumljivo i prihvatljivo tumačiti razlike $u$ trajanju pogleda $\mathrm{u}$ različitim eksperimentalnim uvjetima razlikama $\mathrm{u}$ vremenu potrebnom za identificiranje i obradu riječi (Pollatsek i sur., 2006).

U jednoj od posljednjih objavljenih inačica modela (E-Z Reader 10) u glavne postavke modela uključene su i više razine obrade. Dvije su novosti u odnosu na starije inačice. Prva jest ta da preusmjeravanje pažnje s jedne riječi na drugu nije trenutačna, već iziskuje određeno vrijeme, a druga se odnosi na dodavanje nove postavke dotadašnjem modelu. Pridodana stavka nosi naziv postleksička integracijska faza koja započinje odmah po identifikaciji riječi $n$, odnosno nakon što je faza L2 na toj riječi završena. Ova faza odražava sve stavke postleksičke obrade nužne kako bi se riječ $n$ integrirala u reprezentacije više razine (primjerice, povezivanje riječi $n$ u sintaktičku strukturu, generiranje prikladnih semantičkih reprezentacija 


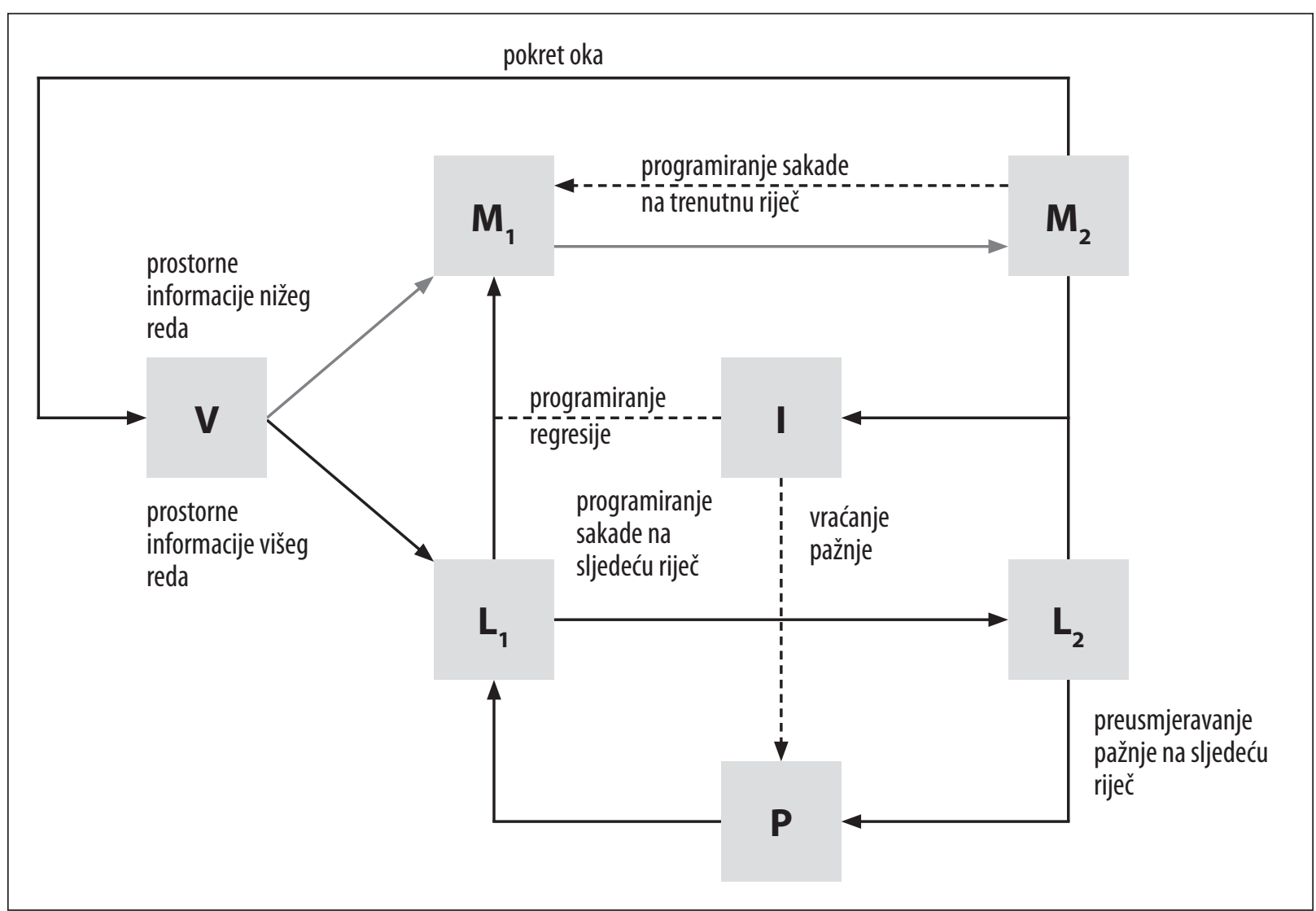

Slika 1. Shematski prikaz E-Z Reader 10 modela, s pretpostavkom o preusmjeravanju pažnje (P) i postleksičkoj integraciji (I) (preuzeto i prilagođeno od Reichle i sur., 2009). V predstavlja vizualne informacije koje se obrađuju prije leksičkih faza obrade (L1) i (L2). Vizualne informacije nižeg reda su primjerice prazni prostori između riječi, dok su vizualne informacije višeg reda obilježja koja pomažu čitatelju da identificira pojedine grafeme. Deblje strelice prikazuju protok informacija između komponenata modela, tanke strelice prikazuju neizostavne prijelaze iz jedne sastavnice modela u drugu, a tanke isprekidane strelice prikazuju moguće prijelaze između komponenata.

te ugrađivanje značenja riječi u diskurs) (za više detalja vidi Sliku 1 u nastavku, ali i Reichle i sur., 2009).

\section{Model SWIFT}

SWIFT (Engbert i sur., 2002) je drugi najpoznatiji model koji svojim postavkama nastoji objasniti procese u pozadini pokreta očiju tijekom čitanja, ali na nešto drugačiji način. Teorijski su se pristupi modela tijekom godina razvijali, međutim temeljne su postavke ostale konstantne (Engbert i Klieg1, 2001; Engbert i sur., 2002; Engbert i sur., 2004; Engbert i sur., 2005; Richter i sur., 2006 itd.). Prva od dviju glavnih pretpostavki modela jest da pažnja može biti usmjerena na više riječi istovremeno, odnosno da je moguća istovremena leksička obrada dviju ili više riječi. Druga jest da se odlu- ka o tome u kojem smjeru pomaknuti oko određuje nasumično, tj. da se sakade programiraju u nasumičnim intervalima pri čemu čimbenici poput čestotnosti riječi na trajanje fiksacija utječu isključivo neizravno (odgađa se programiranje sakada, a trajanje fiksacije se produžuje). Programiranje sakada vođeno je fovealnom inhibicijom koja ima svrhu produžavanja vremena uvida u složene riječi. Ova inhibicija uključuje odgodu vremena jer se temelji na sporijem prepoznavanju riječi. Kao i u E-Z Reader-u, i u SWIFT-u postoje labilna i nelabilna faza u programiranju sakada. Za SWIFT je karakteristično i postojanje dvaju odvojenih putova za njihovo programiranje; prostorni put ( $g d j e$ ) i vremenski (kada). U model su ugrađene i sistematične ili nasumične pogreške u duljini sakada te ispravak netočno lociranih fiksacija (Engbert i sur., 2005). Za shematski prikaz modela vidi Sliku 2. 


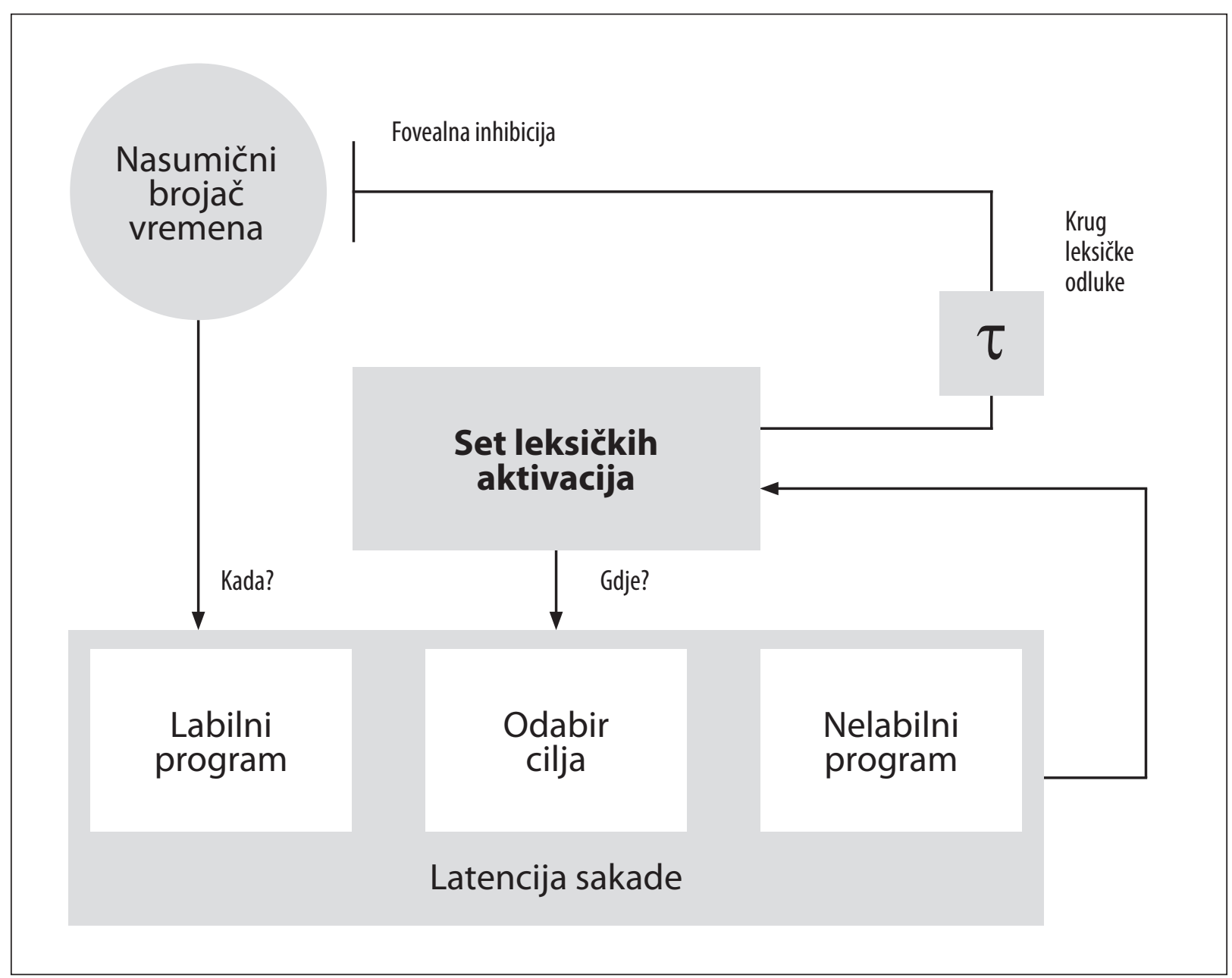

Slika 2. Shematski prikaz SWIFT modela (preuzeto i prilagođeno od Engbert i sur., 2005).

Iako poznat i često spominjan, ovaj model ni do danas nije uspio objasniti kako više razine obrade utječu na čitanje, kao što je to slučaj sa zadnjom inačicom E-Z Readera (E-Z Reader 10$)$, a što je prethodno opisano. Dapače, tvorci SWIFT modela njegov nedostatak informacija o višim razinama obrade opravdavaju činjenicom da jezični procesi više razine ključni za razumijevanje pročitanog u osnovi imaju maleni utjecaj na kontrolu pokreta očiju tijekom čitanja (Engbert i sur., 2005).

\section{Usporedba dvaju modela}

Kako bi prikaz navedenih dvaju modela bio još jasniji, dovest će ih se u vezu prikazom glavnih razlika. Glavna se razlika odnosi na način preusmjeravanja pažnje prilikom obrade; E-Z Reader (Reichle i sur., 1998) je model serijskog preusmjeravanja pažnje (engl. serial attention shift; $S A S$ ) što znači da podrazumijeva serijsku leksičku obradu, dok je SWIFT (Engbert i sur., 2002) model paralelnog preusmjeravanja pažnje (engl. gradient by attention guidance; $G A G$ ), odnosno ne isključuje mogućnost paralelne leksičke obrade u kojoj tijekom fiksacije istovremeno može biti obrađeno više od jedne riječi. Modeli se razlikuju i s obzirom na kognitivne i leksičke utjecaje na trajanje fiksacije. U E-Z Reader-u kognitivni i leksički procesi imaju značajan utjecaj na pokrete očiju, dok su u SWIFT-u sakade autonomne, s tek povremenim kognitivnim utjecajima. U oba je modela očit vrlo ran utjecaj čestotnosti i predvidljivosti riječi na trajanje fiksacija. Postoje istraživanja koja idu u prilog jednom i drugom modelu, a rasprave i neki temeljni prijepori i dalje su aktualni. Za vrlo detaljan prikaz razlika, kao i dokaza koji idu u prilog modelima, vidi Rayner, 2009. 


\section{ZAKLJUČAK}

Cilj je ovog rada bio dati kratki prikaz metoda koje pružaju uvid u jezičnu obradu u odgođenom i u stvarnom vremenu, s posebnim naglaskom na metodu praćenja pokreta očiju. Ova metoda primjerena je budući da je neinvazivna, a temelji se na pretpostavkama koje povezuju fiziološku razinu kontrole pokreta oka s pozadinskim kognitivnim procesima (spomenuta pretpostavka oko-um). Uz to, pruža jasan uvid u strategije odlučivanja, iznimno je osjetljiva na vremensku dimenziju, a pogodna je za istraživanje jezične obrade ljudi svih životnih dobi. U istraživanjima se koriste paradigme čitanja i slušanja, pri čemu čitanje predstavlja vrlo strukturiran proces u kojem se može očekivati gdje će u tekstu čitatelj početi, a gdje završiti i kojim će se smjerom pokreti oka odvijati. Načelno ne postoji opće slaganje oko određivanja procesa uključenih u čitanje i upravo zbog složenosti jezične obrade postoji velik broj modela koji nastoje objasniti ovu vještinu. Razlike u opisima modela proizlaze iz prijepora poput povezanosti određe- nih pokreta oka s komponentama jezične obrade ili kognitivnih funkcija; potom pitanja o tome jesu li procesi koji se tijekom čitanja odvijaju serijski ili paralelni; što sve oni zaista uključuju te kako točno izgleda njihova kognitivna arhitektura. U ovome radu predstavljen je kratki pregled najpoznatijih modela koji može biti obavijestan čitateljima. Sva ostala pitanja (primjerice, objašnjenja nekih poremećaja poput disleksije, o čemu se sve više raspravlja u ovom kontekstu) ipak prelaze okvire ovog rada te su ostavljena za buduća istraživanja.

\section{ZAHVALE}

Ovaj je rad nastao u sklopu nacionalnog projekta Jezična obrada u odraslih govornika (Hrvatska zaklada za znanost UIP-11-2013-2421), pod voditeljstvom izv. prof. dr. sc. Jelene Kuvač Kraljević.

Posebnu zahvalu upućujem izv. prof. dr. sc. Marijanu Palmoviću, za sve korisne savjete tijekom pisanja ovog rada. 


\section{LITERATURA}

Aaronson, D., Scarborough, H. S. (1976): Performance theories for sentence coding: some quantitative evidence. Journal of Experimental Psychology: Human perception and performance, 2(1), 56-70.

Altmann, G., Steedman, M. (1988): Interaction with context during human sentence processing. Cognition, 30(3), 191-238.

Ambridge, B., Rowland, C. F. (2013): Experimental methods in studying child language acquisition. Wiley Interdisciplinary Reviews: Cognitive Science, 4(2), 149-168.

Anderson, J. R., Bothell. D., Douglass, S. (2004): Eye movements do not reflect retrieval processes limits of the eyemind hypothesis. Psychological Science, 15(4), 225-231.

Ashby, J., Rayner, K. (2004): Representing syllable information during silent reading: evidence from eye movements. Language and Cognitive Processes, 19(3), 391-426.

Buswell, G. T. (1922): Fundamental reading habits: a study of their development. Chicago: University of Chicago Press.

Carreiras, M., Clifton C. Jr. (2004): On the on-line study of language comprehension. U Carreiras, M., Clifton, C. Jr. (ur.): The on-line study of sentence comprehension: Eyetracking, ERPs and beyond. (str. 1-14). New York: Psychology Press.

Clahsen, H. (2008): Behavioral methods for investigating morphological and syntactic processing in children. U Sekerina, I., Fernández, E. M., Clahsen H. (ur.): Developmental psycholinguistics: online methods in children's language processing. (str. 1-27). Amsterdam: Benjamins.

Clifton, C. Jr., Staub, A. (2011): Syntactic influences on eye movements during reading. Eye, 3, 2. Posjećeno 10. prosinca 2016. na mrežnoj stranici: http://people.umass.edu/astaub/CliftonStaub_eyetrackinghandbook_preprint.pdf

Dopkins, S., Morris, R. K., Rayner, K. (1992): Lexical ambiguity and eye fixations in reading: a test of competing models of lexical ambiguity resolution. Journal of Memory and Language, 31(4), 461-476.

Engbert, R., Kliegl, R. (2001): Mathematical models of eye movements in reading: a possible role for autonomous saccades. Biological Cybernetics, 85(2), 77-87.

Engbert, R., Longtin, A., Kliegl, R. (2002): A dynamical model of saccade generation in reading based on spatially distributed lexical processing. Vision Research, 42, 621-636.

Engbert, R., Kliegl, R., Longtin, A. (2004): Complexity of eye movements in reading. International Journal of Bifurcation and Chaos, 14(02), 493-503.

Engbert, R., Nuthmann, A., Richter, E. M., Kliegl, R. (2005): SWIFT: a dynamical model of saccade generation during reading. Psychological Review, 112(4), 777-813.

Feng, G. (2006): Eye movements as time-series random variables: A stochastic model of eye movement control in reading. Cognitive Systems Research, 7(1), 70-95.

Gerken, L., Shady, M. E. (1998): The picture selection task. U McDaniel, D., McKee, C., Cairns, H. (ur.): Methods for assessing children's syntax. (str. 125-146). London: MIT Press.

Goodluck, H. (1998): The act-out task. U McDaniel, D., McKee, C., Cairns, H. (ur.): Methods for assessing children's syntax. (str. 147-162). London: MIT Press.

Gordon, P. (1998): The Truth-value judgment task. U McDaniel, D., McKee, C., Cairns, H. (ur.): Methods for assessing children's syntax. (str. 211-232). London: MIT Press.

Henderson, J. M., Ferreira, F. (1990): Effects of foveal processing difficulty on the perceptual spin in reading: implications for attention and eye movement control. Journal of Experimental Psychology: Learning, Memory and Cognition, 16, 417-429.

Hill, R. L., Murray W. (2000): Commas and spaces: effects of punctuation on eye movements and sentence processing. U Kennedy, A., Heller, D., Pynte, J. (ur.): Reading as a perceptual process. (str. 565-589). Amsterdam: Elsevier. 
Jegerski, J. (2014): Self-paced reading. U Jegerski, J., Van Patten, B. (ur.): Research methods in second language psycholinguistics. (str. 20-49). New York: Routledge.

Jensen, A. (2006): Clocking the mind: mental chronometry and individual differences. Amsterdam: Elsevier.

Jiang, N. (2013): Conducting reaction time research in second language studies. New York: Routledge, Taylor and Francis Group.

Just, M. A., Carpenter, P. A. (1980): A theory of reading: from eye fixations to comprehension. Psychological Review, 87(4), 329-354.

Just, M. A., Carpenter, P. A., Woolley, J. D. (1982): Paradigms and processes in reading comprehension. Journal of Experimental Psychology: General, 111(2), 228-238.

Kamide, Y., Altmann, G. T. M., Haywood, S. L. (2003): The time-course of prediction in incremental sentence processing: Evidence from anticipatory eye movements. Journal of Memory and Language, 49(1), 133-156.

Kolers, P. A., Duchnicky, R. L., Ferguson, D. C. (1981): Eye movement measurement of readability of CRT displays. Human factors: The Journal Of The Human Factors And Ergonomics Society, 23(5), 517-527.

Lee, Y. A., Binder, K. S., Kim, J. O., Pollatsek, A., Rayner, K. (1999): Activation of phonological codes during eye fixations in reading. Journal of Experimental Psychology: Human perception and performance, 25(4), 948-964.

Marinis, T. (2010): Using on-line processing methods in language acquisition research. U Unsworth, S., Blom, E. (ur.): Experimental methods in language acquisition research. (str. 139-162). Amsterdam: John Benjamins (Language Learning and Language Teaching).

McDonald, S. A., Carpenter, R. H. S., Shillcock, R. C. (2005): An anatomically constrained, stochastic model of eye movement control in reading. Psychological review, 112(4), 814.

McKercher, D. A., Jaswal, V. K. (2011): Using judgment tasks to study language knowledge. U Hoff, E. (ur.): Research methods in child language: a practical guide (str. 149-161). New York: John Wiley and Sons.

Millis, K. K., Just, M. A. (1994): The influence of connectives on sentence comprehension. Journal of Memory and Language, 33(1), 128-147.

Morrison, R. E. (1984): Manipulation of stimulus onset delay in reading: evidence for parallel programming of saccades. Journal of Experimental Psychology: Human perception and performance, 10, 667-682.

Morrison, R. E., Inhoff, A. W. (1981): Visual factors and eye movements in reading. Visible Language, 15(2), 129-146.

Osaka, N. (1989): Eye fixation and saccade during kana and kanji text reading: comparison of English and Japanese text processing. Bulletin of the Psychonomic Society, 27(6), 548-550.

Pollatsek, A., Hyönä, J., Bertram, R. (2000): The role of morphological constituents in reading Finnish compound words. Journal of Experimental Psychology: Human perception and performance, 26(2), 820-833.

Pollatsek, A., Reichle, E. D., Rayner, K. (2006): Tests of the EZ Reader model: exploring the interface between cognition and eye-movement control. Cognitive Psychology, 52(1), 1-56.

Rayner, K. (1984): Visual selection in reading, picture perception, and visual search: a tutorial review. U Bouma, H., Bouwhuis, D. (ur.): Attention and performance (Vol. 10). (str. 67-96). Hillsdale, NJ: Erlbaum.

Rayner, K. (1998): Eye movements in reading and information processing: 20 years of research. Psychological Bulletin, 124(3), 372-422.

Rayner, K. (2009): Eye movements in reading: models and data. Journal of Eye Movement Research, 2(5), 1-10.

Rayner, K., Duffy, S. A. (1986): Lexical complexity and fixation times in reading: effects of word frequency, verb complexity, and lexical ambiguity. Memory \& Cognition, 14(3), 191-201.

Rayner, K., Reichle, E. D. (2010): Models of the reading process. Wiley Interdisciplinary Reviews: Cognitive Science, 1(6), 787-799. 
Reichle, E. D., Pollatsek, A., Fisher, D. L., Rayner, K. (1998): Toward a model of eye movement control in reading. Psychological Review, 105(1), 125-157.

Reichle, E. D., Rayner, K. (2000): Comparing the EZ reader model to other models of eye movement control in reading. Posjećeno 5. prosinca 2016. na mrežnoj stranici: https://www.ncbi.nlm.nih.gov/pmc/articles/PMC2906818/pdf/ nihms188811.pdf

Reichle, E. D., Rayner, K., Pollatsek, A. (2003): The EZ Reader model of eye-movement control in reading: comparisons to other models. Behavioral and Brain Sciences, 26(4), 445-476.

Reichle, E. D., Warren, T., McConnell, K. (2009): Using EZ Reader to model the effects of higher level language processing on eye movements during reading. Psychonomic Bulletin \& Review, 16(1), 1-21.

Reilly, R. G., Radach, R. (2006): Some empirical tests of an interactive activation model of eye movement control in reading. Cognitive Systems Research, 7(1), 34-55.

Richter, E. M., Engbert, R., Kliegl, R. (2006): Current advances in SWIFT. Cognitive Systems Research, 7(1), 23-33.

Salvucci, D. D. (2001): An integrated model of eye movements and visual encoding. Cognitive Systems Research, 1(4), 201-220.

Schmitt, C., Miller, K. (2010): Using comprehension methods in language acquisition research. U Unsworth, S., Blom, E. (ur.): Experimental methods in language acquisition research. (str. 35-57). Amsterdam: John Benjamins (Language Learning and Language Teaching).

Schroyens, W., Vitu, F., Brysbaert, M., D’Ydewalle, G. (1999): Eye movement control during reading: foveal load and parafoveal processing. The Quarterly Journal of Experimental Psychology: Section A, 52(4), 1021-1046.

Sedivy, J. C. (2010): Using eyetracking in language acquisition research. U Unsworth, S., Blom, E. (ur.): Experimental methods in language acquisition research. (str. 115-139). Amsterdam: John Benjamins (Language Learning and Language Teaching).

Sekerina, I. A., Fernández E. M., Clahsen, H. (2008): Introduction. U Sekerina, I., Fernández, E. M., Clahsen H. (ur.): Developmental psycholinguistics: online methods in children's language processing. (str. 7-15). Amsterdam: Benjamins.

Snow, C. E., Burns, S. M., Griffin, P. (ur.) (1998): Preventing reading difficulties in young children. Washington DC: National Academies Press.

Tanenhaus, M. K., Spivey-Knowlton, M. J., Eberhard, K. M., Sedivy, J. C. (1995): Integration of visual and linguistic information in spoken language comprehension. Science, 268(5217), 1632-1634.

Tremblay, A. (2005): Theoretical and methodological perspectives on the use of grammaticality judgment tasks in linguistic theory. Second Language Studies, 24(1), 129-167.

Warren, T., White, S. J., Reichle, E. D. (2009): Investigating the causes of wrap-up effects: evidence from eye movements and E-Z Reader. Cognition, 111(1), 132-137.

Yang, S. N., McConkie, G. W. (2001): Eye movements during reading: A theory of saccade initiation times. Vision research, 41(25), 3567-3585. 


\section{CHARACTERISTICS OF EYE MOVEMENTS AND MODELS OF READING BASED ON THE USE OF EYE-TRACKING}

Abstract: Over the last few decades many methods for studying the underlying mechanisms of language processing have been developed. They can roughly be divided into off-line and on-line methods, and differences between them involve how they are carried out, as well as the type and characteristics of data they provide.

The eye-tracking method is considered one of the best methods for studying language processing. It provides insights into cognitive processes in real time. As opposed to off-line, and also some on-line methods, i.e. cognitive evoked potentials or functional magnetic resonance, it is especially suitable for studying processes that spread over time. Considering the fact that it is based on assumptions that connect the physiological level of eye movement control with the underlying cognitive processes, and is also non-invasive, it is becoming more and more present when it comes to studying language processing.

The main aim of this paper was to provide a brief overview of the methods for studying language processing with special emphasis on the on-line eye-tracking method, to introduce the characteristics of eye movements during reading and to present some of the most influential models of reading. Even though language processing in eye-tracking can be studied through either reading or listening, for the purpose of this paper the emphasis has been put on the reading paradigm.

Key words: language processing, on-line methods, eye-tracking, models of reading. 